synangia, groups of sporangia borne on the surface of a leaf-like structure, or organs resembling the male flowers of the poplar. Nothing is known of a fertile leaf like that envisaged in the classical morphology. The study of these forms, however, suggests that angiospermous flowers may have originated in more than one way.

When we examine the forms of expanded leaves throughout the past, it is impossible to avoid the conclusion that 'compound' leaves are of a more primitive type than 'simple' leaves. In certain cases, however (for example, the Date palm), a new type of compound leaf has probably arisen from a simple form.

In other branches of science the interpretation of observed facts is facilitated by making successive assumptions and by comparing the theoretical results of each with the observations already made. This procedure has not been followed in plant morphology. The old system provided one set of assumptions only, founded more than a century ago on a very imperfect knowledge of the plant world, and for many years endeavours have been made to harmonise our ever-increasing observations with these postulates, distorting or discarding all those facts which seemed inconsistent. While it is quite probable that the assumptions of the new morphology may prove to need drastic emendation, they may nevertheless serve a useful purpose in the study of plant evolution.

\title{
Obituary
}

\section{Mr. H. A. RoBerts}

$\mathrm{M}^{\mathrm{R}}$ R. H. A. ROBERTS, secretary for thirty years of the Appointments Board of the University of Cambridge, died at Cambridge on December 18 at the age of sixty-eight years. After ten years as senior mathematical master at Bath College he returned to Cambridge as a coach in mathematics in 1898. But his life's real work began when he was appointed in 1902 to be secretary of the University Appointments Board. He waskeen to develop a new line of openings for university graduates in business and administrative posts, in addition to the more obviously natural academic, professional and technical positions which most men then sought after graduation. By great care in the selection of the men whom he recommended to the firms which applied to the Board, he not only succeeded in overcoming a prejudice against university men in business but he also created a new demand for such men on the part of large industrial undertakings.

Thirty years of devoted service on Mr. Roberts's part brought their own reward in intimate and friendly relations with the heads of industry, with their younger successors who had gone into business under his auspices, and with generations of college tutors, with whom he always worked in the closest touch. Gonville and Caius College elected Mr. Roberts as a Fellow in 1927, his advice was sought in Government circles and in the formation of appointments boards at other universities and for the women's colleges at Cambridge. He retired on account of ill-health only last autumn. It is sad that he should have lived so short a time to enjoy his hard-won leisure, but it is something that he was able to attend, less than a fortnight before his death, a complimentary dinner at which a presentation was made to him on his retirement by a number of those whom he had served so well.

\section{Mr. A. R. WRIGHT}

Mr. A. R. Wright, who died on December 24 at the age of seventy years, played an important part in organising the work of the examining staff of the Patent Office to its present high level of efficiency and was also a recognised authority on folk-lore.

Wright entered the Patent Office in 1885 and from that date until his retirement forty-two years later worked unremittingly to place the classification of patent specifications for search purposes on a sure foundation. He was the editor of the well-known official series of illustrated class abridgment volumes which were published at the rate of more than fifty volumes a year to cover, by the year 1905, all patent specifications issued up to that time from 1855. The classification scheme on which this mass of material was indexed and through which alone the official search for novelty introduced by the Patents Act of 1902 was made possible, was largely Wright's work, and its amplification in subsequent years to meet the evergrowing amount of search material in the examiners' files and the development of industries and industrial processes was carried out under his personal supervision with a thoroughness and care for detail which were characteristic of the man.

The Patent Office classification as it stands to-day, exceptional in many respects, deserves a high place among the several developed classifications of applied science, and is a worthy memorial to Wright's energy and capacity. He was appointed assistant-comptroller of the Patent Office in 1922, while still retaining the classification as his main charge, and retired from the service in 1927.

As a folklorist, Wright was known not so much for his literary output, which was not large, as for his encyclopædic knowledge of folk beliefs and customs, obtained by extensive reading and an unusually retentive memory, which was ever at the disposal of anyone seeking information, and for the valuable services he rendered through the Folk-Lore Society, of which he became a member in 1890 . He was a prominent and active member of the Council of the Society from 1898 until his death, and president for the two years 1927 and 1928, while he was an invaluable editor of the Society's journal Folk-Lore from 1912 until 1931. 